\title{
446 粒状体ダンパの減衰メカニズムに関する研究
}

（粒状体の挙動観察と減衰特性）

\section{Damping Mechanisms of Vibration Reduction System with Granular Materials (Observation of Motion of Granular Materials and Damping Characteristics)}

$\bigcirc$ 谷島 誠(東京電機大 院 / 現 : 三菱電機 (株)) 村山 徳和(東京電機大 院)

\author{
正 佐藤 太一（東京電機大） \\ 正 田中 基八郎（埼玉大）
}

\section{Makoto TANISHIMA, Graduate School of Tokyo Denki University, Hatoyama, Hiki-gun, Saitama Taichi SATO, Tokyo Denki University \\ Norikazu MURAYAMA, Graduate School of Tokyo Denki University KihachiroTANAKA, Saitama University}

\begin{abstract}
Experimental investigation into the dynamic behavior of vibration system with granular materials has been carried out using forced vibration system with single degree of freedom. The vibration system was excited in forced vibration by foundation motion at the natural frequency of the system, and two accelerometers were used to simultaneously measure their respective accelerations. We took a motion of the granular materials with a high speed videocam and analyzed their motions. We then discuss the relationship between the damping characteristics and the behavior of granular materials. Furthermore, we evaluated vibration characteristics of the damper when diameter of granular materials and depth of the granular-container were changed.
\end{abstract}

Key Words: Damper, Granular Materials, High Speed Videocam, Single Degree of Freedom System, Damping Ratio, Damping Mechanism

\section{A1。緒言}

前報において, 粒状体ダンパの減衰メカニズムを明らかに するために, 図A1に示すような粒状体の等価付加質量 $\mathrm{m}_{\mathrm{eq}}$ を 提案し, 粒状体の運動を大局的に把握することを試みた.そ して,ダンパの制振特性を粒状体の等価付加質量に関連させ て考察した。 また, 粒状体の質量, 粒状体淔径, 基礎加振加 速度の大きさと制振特性の関倸を検討した。

本報告では，粒状体の挙動を高速度ビデオカメラで撮影 し,粒状体の挙動と制振特性とがどのような関係にあるかを 検討する.さらに, 粒状体直径および粒状体容器の寸法と制 振特性との関係を議論する。

\section{A2. 実験方法}

油圧加振機により,実験装置の基礎部に水平方向の変位強 制荷重を与えた。実験装置（振動系）の固有振動数 $(54 \mathrm{~Hz})$ で定常加振を行い,粒状体容器と基礎部にそれぞれ加速度計 を取り付け，雨者の加速度を同時に計測した．また，それと 同時に高速度ビデオカメラを用いて粒状体の運動を撮影し た. その後, 粒状体の挙動を「並進」,「回転」,「停止」の三 つの運動に分けた。

\section{A3. 実験結果}

粒状体質量を $0 \mathrm{~kg}$ から $8 \mathrm{~kg}$ まで $1 \mathrm{~kg}$ 刻みで増加させて実験を 行った.「並進」,「回転」,「停止」の各挙動の質量の推移を図 A2に示す.また, 減衰比と相対運動質量 $\left(m-m_{\mathrm{eq}}\right)$ の推移を 図A3に示す.

図A2と図A3とを比較した結果,『相対運動質量はほぼ「並 進」の質量を表す』，『「並進」ならびに「回転」の質量が 増加するときに減衰比が増加する』ことが明らかとなった。

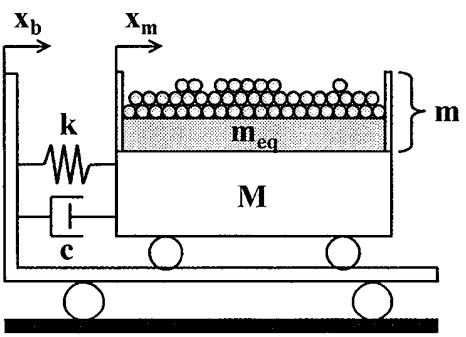

Fig. A1 Model of vibration system with granular materials

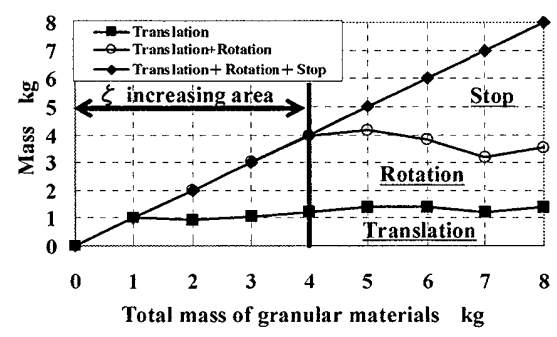

Fig.A2 Actual map of mass of "Translation",

"Rotation" and "Stop" (Diameter: 6mm)

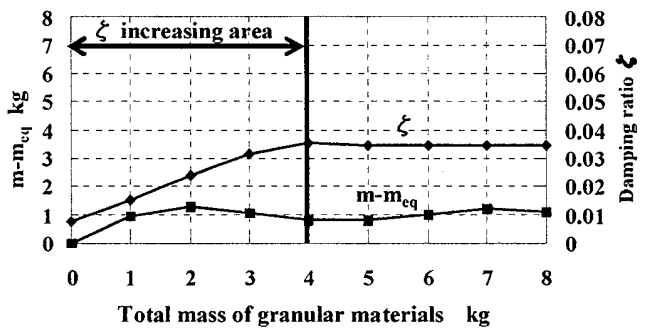

Fig.A3 Relationship between damping ratio, $\mathrm{m}-\mathrm{m}_{\mathrm{eq}}$ and total mass of granular materials (Diameter: $6 \mathrm{~mm}$ )

日本機械学会 [No.07-8] Dynamics and Design Conference 2007 CD-ROM論文集 [2007.9.25-28,東広島] 


\section{1. 緒言}

粒状体ダンパは, 振動系に容器を設けて, その容器に粒 状体を封入するだけで構成されるダンパである。このよう な簡単な構成である一方, 粒状体ダンパは多くの粒状体を 有するため，そのダンピングのメカニズムが十分解明され

ているとは言えない。

粒状体ダンパの制振特性に関して，粒状体を有する 1 自 由度振動系の振動挙動が，個別要素法を用いて佐伯らに よって計算・検討されている(1)(2)。一方, 粒状体ダンパを製 品に応用しようと試みた報告として, 磁気共鳴イメージン グ装置, 鉄道車両における一本リンクを対象とした報告が ある(3)(4)

著者らは，前報において，粒状体ダンパの減衰メカニズ ムを明らかにするために，粒状体の等価付加質量を提案し， 粒状体の運動を大局的に把握することを試みた.そして,ダ ンパの制振特性を粒状体の等価付加質量に関連させて考察し た. また, 粒状体の質量, 粒状体直径, 基礎加振加速度の大 きさと制振特性の関係を検討した(5)

本報告では, 粒状体の挙動を高速度ビデオカメラで撮影 し，粒状体の挙動と制振特性とがどのような関係にあるか を検討する.さらに, 粒状体直径および粒状体容器の寸法 と制振特性との関倸を議論する。

\section{2. 実験装置とその振動モデル}

実験装置の概略を図 1 に，仕様を表 1 に示す，図の中央が 粒状体を入れる容器である。この容器は, 振動系の質量部 を兼ねている．剛性の高いベースには二枚の板（はり）が 各々両端固定されている，粒状体容器は，はりの中央にね じ止めされる。つまり，二つのはりが粒状体容器 (質量部) を支持するば权となっている。

本実験装置は，図 2 に示す粒状体を有する 1 自由度振動 系でモデル化できる ${ }^{(5)}$. 粒状体の質量（総質量）は m で表 記している. 粒状体は, 前報で述べたように, 二つに分けら れ, 粒状体の一部が付加質量 $\left(\mathrm{m}_{\mathrm{eq}}\right)$ として, 他の質量 $(\mathrm{m}$ - $\left.\mathrm{m}_{\mathrm{eq}}\right)$ が自由に運動する質量として振る舞う.その結果, 振 動系の質量は，振動系の質量 $\mathrm{M} に$ 付加質量 $\mathrm{m}_{\mathrm{eq}}$ を加えたも のになる。 また，総質量から付加質量を差し引いた $(\mathrm{m}-$ $\left.\mathrm{m}_{\mathrm{eq}}\right)$ は振動系とは別の動きをする質量であり，本報告では $\left(\mathrm{m}-\mathrm{m}_{\mathrm{eq}}\right)$ を相対運動質量と呼ぶ.

\section{3. 粒状体の挙動解析}

\section{$3 \cdot 1$ 実験方法及び解析方法}

油圧加振機により,実験装置の基礎部に水平方向の変位 強制荷重を与えた. 実験装置(振動系) の固有振動数 $(54 \mathrm{~Hz})$ で定常加振を行い, 粒状体容器と基礎部にそれぞれ加速度計

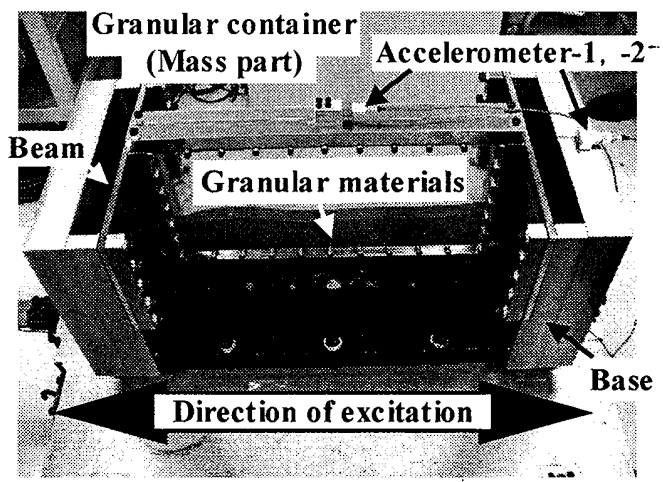

(a) Top view

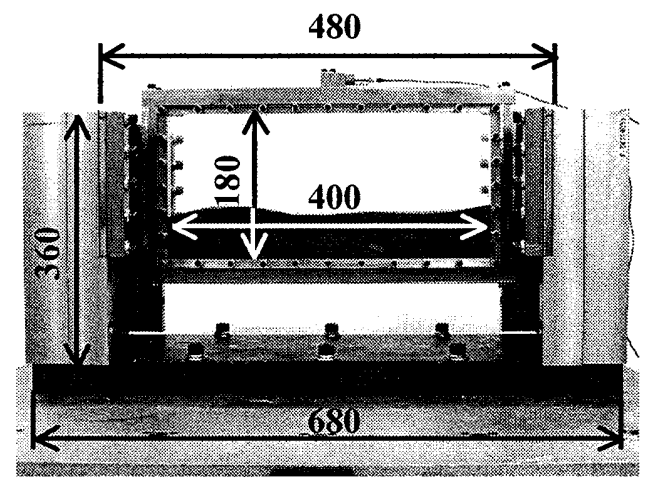

(b) Front view

Fig.1 Schematic diagram of experimental device

Table1 Specification of experimental device

\begin{tabular}{c||c}
\hline Primary mass of mass part & $16.4 \mathrm{~kg}$ \\
\hline Spring constant & $1860 \mathrm{kN} / \mathrm{m}$ \\
\hline Natural frequency & $54 \mathrm{~Hz}$ \\
\hline
\end{tabular}

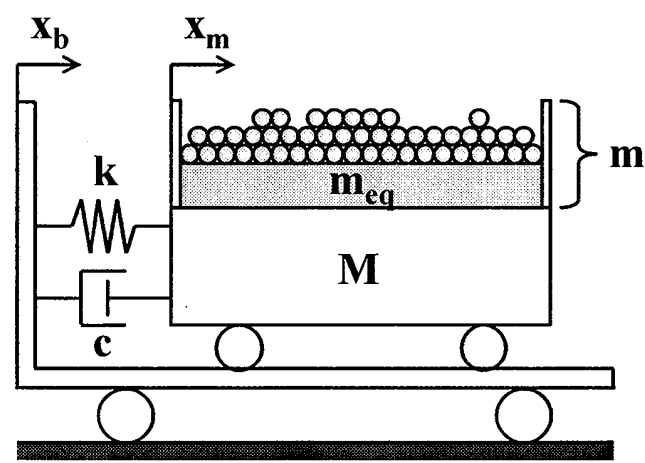

Fig.2 Model of vibration system with granualar materials

を取り付け，両者の加速度を同時に計測した．また，それと 同時に高速度ビデオカメラを用いて粒状体の運動を撮影し た.

粒状体の挙動を観察した結果, 粒状体の挙動は大きく分 けて3種類に分けられることが分かった. 粒状体が，「並進 もしくは並進しながら回転している状態」,「回転のみして 
いる状態」「停止している状態」の 3 種類である. なお, こ れらの運動を簡単にそれぞれ「並進」、「回転」,「停止」と 呼ぶこととする。

なお,これら三つの挙動の判別は, 高速度ビデオカメラ の撮影結果を画像解析ソフトあるいは視察によって行った。 画像解析ソフトを用いれば, 粒状体の水平方向の運動を計 測することが可能である。この方法によって「並進」とそれ 以外の挙動を区分した.一方, 画像解析ンフトでは「回転」 と「停止」の区分けは困難であった。このため,撮影した結 果を観察することで，雨者の区分けを行った．

一例として, 図 3 に粒状体直径 $6 \mathrm{~mm}$, 粒状体質量 $8 \mathrm{~kg}$ の ときの挙動分布を示す.粒状体の挙動は上から順に「並進」, 「回転」「停止」となっており，下方になるに従って動きに くくなることが分かる.

\section{$3 \cdot 2$ 減衰比と相対運動質量の結果から推論した粒状 体の兴動}

図 4 は，粒状体質量を変化させたときの減衰比と相対運 動質量 $\left(m-m_{e q}\right)$ の推移を示している. 図の横軸には粒状体 総質量 $m$ を, 縦軸には相対運動質量 $\left(m-m_{e q}\right)$ と減衰比の 二つの軸をとっている. なお，等価付加質量 $\mathrm{m}_{\mathrm{eq}}$ の求め方 は，前報で示した通りである(5).

図5は図4の結果に基づいて推論した粒状体の挙動を模式 的に示したものである. 図 40 相対運動質量 $\left(\mathrm{m}-\mathrm{m}_{\mathrm{eq}}\right)$ は自 由に運動する粒状体の質量である。このため, 相対運動質 量の推移は「並進」の推移を表すむのと考えられる.

続いて, 図40減衰比らの推移に目を転じる. 粒状体総質 量 $0 \mathrm{~kg}$ から $4 \mathrm{~kg}$ の領域において減衰比が増加し, その後総 質量を増加しても減衰比は一定となる. 粒状体ダンパは容 器の中に入っている粒状体が動くことにより制振特性が得 られると考えられる. そのため, 減衰比が増加している領 域の $0 \mathrm{~kg}$ から $4 \mathrm{~kg}$ では，粒状体は「並進」あるいは「回転」 の運動をしていると捉えられる。「並進」と「回転」の挙動 の内,「並進」は寸でに相対運動質量から推論した. その推 論を基礎にすれば, 総質量 $1 \mathrm{~kg} か ら 4 \mathrm{~kg}$ の領域において「回 転」の質量が增加すると考えられる。

さらに, 総質量 $4 \mathrm{~kg}$ から $8 \mathrm{~kg}$ の領域について考える。こ の領域では, 先に述べたように減衰比が一定となっている. つまり,この領域では, 総質量を增やしても增やした質量 が減衰比の増加に寄与しない, ということを意味している. 減衰比の増加に寄与しない質量とは,「停止」0質量である.

以上のような推論により,粒状体の挙動が図5のようにな ると考えた。

\section{3 推論した粒状体の兴動と実際の兴動との比較}

図 4 と同じ実験条件で実験を行い, 高速度ビデオカメラ の画像から粒状体の挙動を解析した. 図 3 で示したように 「並進」,「回転」,「停止」の各領域の面積を求め, さらにそ れぞれの面積比に総質量を乗じることで,「並進」「「回転」, 「停止」の各質量を算出した.この実験結果を図 5 と同じ表 記で図 6 に示す.

相刘運動質量と減衰比の挙動から推論して描いた図 5 と 図6とがほぼ一致することが分かる．具体的に説明すれば, 総質量 $1 \mathrm{~kg}$ まで「並進」の質量が増加し, 総質量 $1 \mathrm{~kg}$ 以上

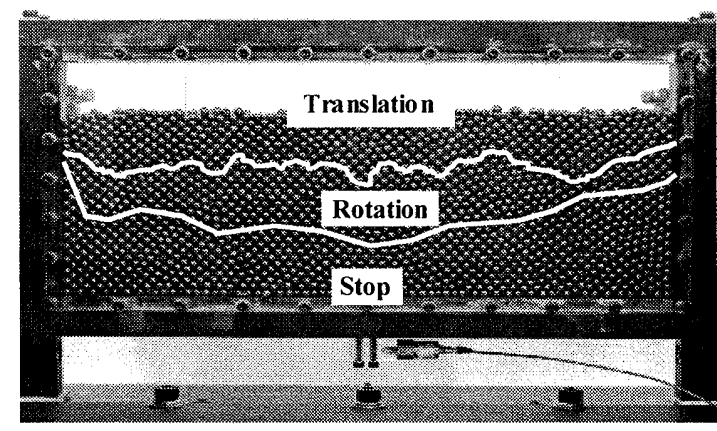

Fig.3 Area of granular materials motion

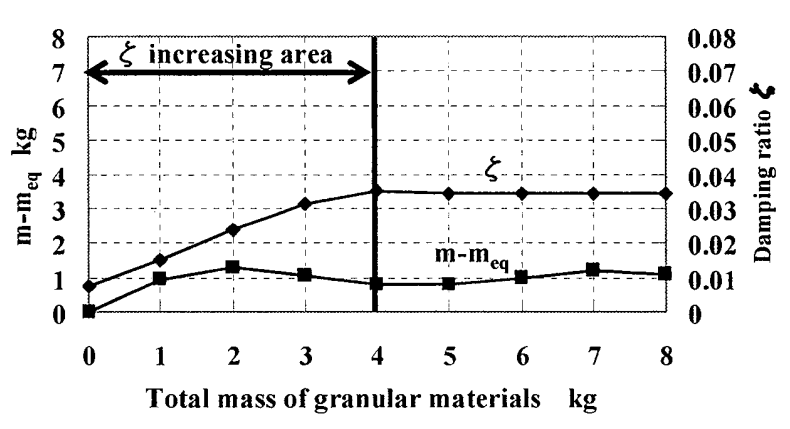

Fig.4 Relationship between damping ratio, $\mathrm{m}-\mathrm{m}_{\mathrm{eq}}$ and total mass of granular materials (Diameter: $6 \mathrm{~mm}$ )

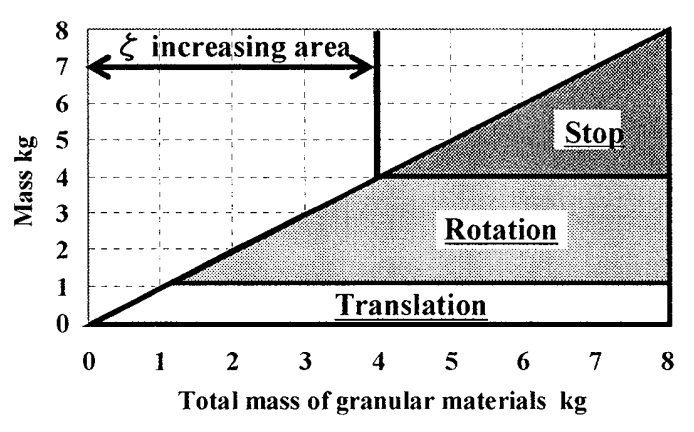

Fig. 5 Predicted map of mass of "Translation",

"Rotation" and "Stop" (Diameter: 6mm)

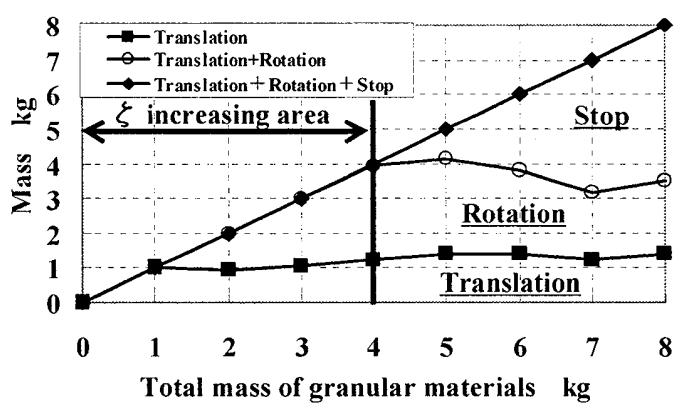

Fig.6 Actual map of mass of "Translation",

"Rotation" and "Stop" (Diameter: 6mm)

ではほぼ一定となっている，続いて，総質量 $1 \mathrm{~kg} か ら ~ 4 \mathrm{~kg}$ の領域において「回転」の質量が増加し, 総質量 $4 \mathrm{~kg}$ 以上 になると「回転」の質量はほぼ一定となる。さらに, 総質量 
を増加しても「停止」の質量が増加するだけになる。これ らの挙動は図 5 , 図 6 ともに同様に認められる.なお, こ のような傾向は他の粒状体直径においても認められた.

まとめると,

・相対運動質量はほぼ「並進」の質量を表す

・並進」ならびに「回転」の質量が増加するときに減衰比 が增加する

という考え方が正しかったと言える．

\section{$\underline{3 \cdot 4}$ 基礎加速度と粒状体の兴動との関係}

前報では, 基礎加速度の大きさが減衰比におよぼす影響 を検討した(5)。ここでは，いずれの粒状体直径においても， 基礎加速度が増えると減衰比が増加するという結果が得ら れた。ここでは,このような基礎加速度と減衰比との関係 を, 粒状体の挙動つまり「並進」,「回転」,「停止」との関 係で考察する.

前報と同条件で実験を行った。使用した粒状体直径は $3 \mathrm{~mm}, 6 \mathrm{~mm}, 10 \mathrm{~mm}$ の 3 種類である。基礎加速度の大き

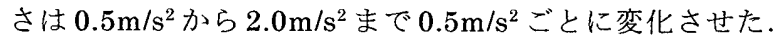

実験結果を図7から図9に示す。図7は粒状体総質量に対 する「並進」の質量の割合，図8は「回転」の割合，図9は 「停止」の割合を示している.図の横軸は基礎加速度の大き さである

基礎加速度が大きくなると，いずれの粒状体直径におい ても「停止」の割合が少なくなる（図 9 )。これは，基礎加 速度が大きくなると粒状体の動く(「並進」十「回転」の) 割合が大きくなり，その結果として減衰比が増加した，と いうことを意味している，さらに，「並進」と「回転」に関 して個別に注目する。「並進」の割合（図７）は基礎加速度 が増加しても，あまり大きな変化はない。一方，「回転」の 質量の割合は基礎加速度の増加とともに増えていることが 分かる（図 8 ）。つまり，基礎加速度が大きくなるとともに 減衰比が大きくなる挙動は, 主に「回転」運動する粒状体 の割合が増加したことに起因している，と言える。

\section{4. 粒状体容器の奥行き寸法と 配列状況と制振特性}

\section{$4 \cdot 1$ 粒状体容器の奥行き寸法と減衰比の関係}

粒状体签器の奥行き寸法を変化させ, その寸法が減衰比 に与える影響を検討した．奥行き寸法を $18 \mathrm{~mm}, 20 \mathrm{~mm}$ ， $25 \mathrm{~mm}$ に固定して実験を行った，粒状体直径として $3 \mathrm{~mm}$, $5 \mathrm{~mm}, 6 \mathrm{~mm}, 8 \mathrm{~mm}, 10 \mathrm{~mm}, 12.5 \mathrm{~mm} の 6$ 種類を用意した。 基礎加速度の大きさは $1.0 \mathrm{~m} / \mathrm{s}^{2}$ である。

減衰比の実験結果を図10に示す.図の横軸仙粒状体直径 である.なお，ここで示している滅衰比は，粒状体質量を 変えていって隇衰比が最大となるときの大きさ(図 4 参照) である，奥行き寸法 $18 \mathrm{~mm}$ の場合には，粒状体直径 $6 \mathrm{~mm}$ の減衰比が大きい. 同様に, 奥行き寸法 $20 \mathrm{~mm}$ の場合には, $5 \mathrm{~mm}$ 玉と $10 \mathrm{~mm}$ 玉の減衰比が，奥行き寸法 $25 \mathrm{~mm}$ の場合 には $12.5 \mathrm{~mm}$ 玉の減衰比が大きい。

粒状体直径と粒状体容器の奥行き寸法とに何らかの関倸

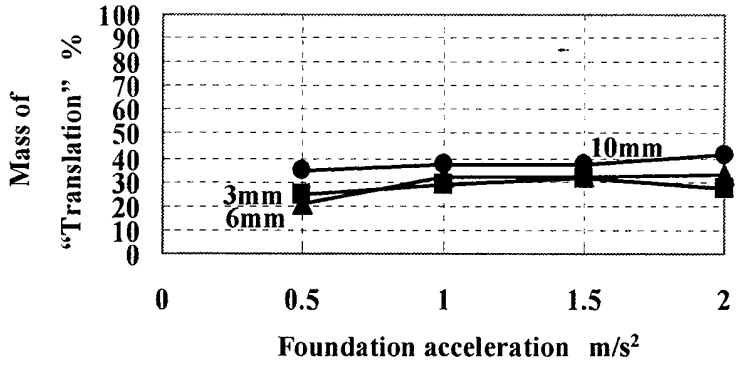

Fig.7 Relationship between mass of "Translation" and foundation acceleration

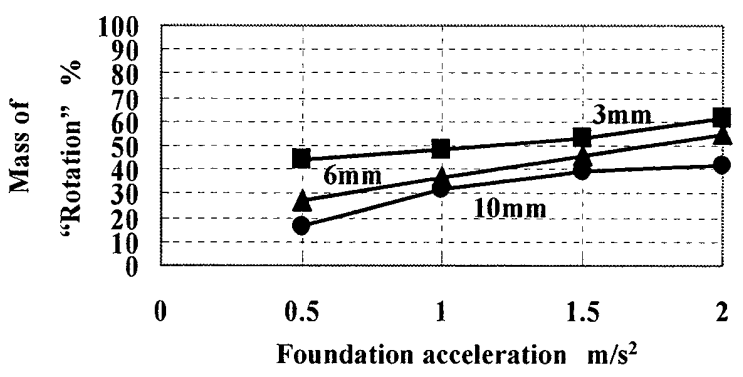

Fig. 8 Relationship between mass of "Rotation" and foundation acceleration

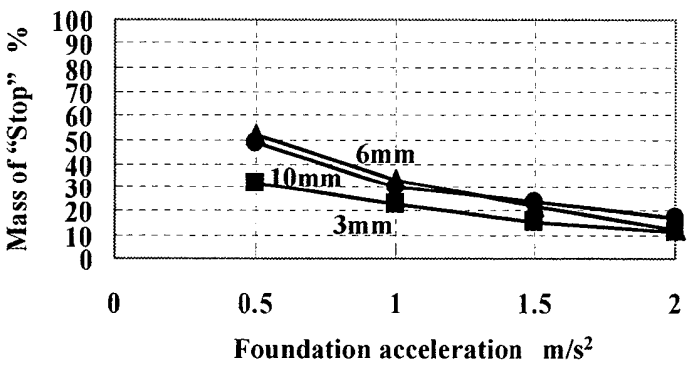

Fig.9 Relationship between mass of "Stop" and foundation acceleration

があると，大きな減衰比が得られることが図10から分かっ た，以下，粒状体直径と奥行き寸法との関係がどのような 場合に減衰比が大きくなるかをさらに検討していく．

\section{$4 \cdot 2$ 粒状体の配列}

図10は, 図中に白丸印で指し示した「減衰比の大きなグ ループ」と，そうでない「減衰比の小さなグループ」に大 別できる.両グループで粒状体がどのように並んでいるか， つまり，配列状況がどのようになっているかを観察した。

図 11,12 はその一例である. 図11 は「減衰比の小さなグ ループ」の一例であり，粒状体直径 $6 \mathrm{~mm}$ ，奥行き寸法 $20 \mathrm{~mm}$ の配列状况である. 図 12 は, 粒状体直径 $6 \mathrm{~mm}$, 奥 行き寸法 $18 \mathrm{~mm}$ の結果，つまり，「減衰比の大きなグルー プ」の結果である、いずれも，図の左が実験装置正面から の写真, 右が上方向から撮影したものである.

図11,12を比較すると次のようなことが分かる.図11(奥 行き寸法 $20 \mathrm{~mm}$ ）の場合には，粒状体の配列はランダムで ある.また,この場合には粒状体と粒状体との間に比較的 大きな隙閒がある。これに対し，図 12 (奥行き寸法 $18 \mathrm{~mm}$ ) 
の場合には，図11に比べて配列が整っており，粒状体と粒 状体との間の隙間が小さい，ただ，図 12 の右側の写真で分 かるように，粒状体の配列を上方向から見ると粒状体はう ねって並んでいる．奥行き寸法をさらに変えることで，よ り整った粒状体の配列が期待できる.そこで, 直径 $6 \mathrm{~mm}$ の 粒状体が斜めに三つ幾何学的に整列する奥行きを求め，そ の奥行き寸法 $16.4 \mathrm{~mm}$ に設定した，そのときの粒状体の配 列状況を図 13 に示す。この場合には，実験装置正面から見 た場合でも，上方向から見た場合でも，いずれも整然とし た並びになっており，隙閒がほとんどないことが分かる。

\section{$4 \cdot 3$ 粒状体の配列と制振特性}

粒状体ダンパにおける減衰効果は, 前述したように, 粒 状体の「並進」ならびに「回転」運動によって得られる。こ うした運動によって粒状体同士に摩擦が生じ, この摩擦が 減衰特性を支配すると考えるならば, 粒状体同士の隙間は 粒状体ダンパの減衰比を支配する重要な値である，と考え られる、先の粒状体の配列状況の観察結果から, 粒状体同 士の隙間は, 粒状体の配列状況に依存するので, 粒状体ダ ンパの減衰比は粒状体の配列状況に影響される, と捉えら れる

そこで, 粒状体直径 $6 \mathrm{~mm}$ の場合について, 粒状体容器の 奥行き寸法を細かく変えながら実験を行った。結果を図 14 に示す. 図の横軸は粒状体容器の奥行き寸法である. 図か ら奥行き寸法が $16.4 \mathrm{~mm}$ のとき減衰比がもっとも高くな ることが分かる.この奥行き寸法は図 130 ○きり寸法であ り，前述したようにこの場合には粒状体は整然と配列して 隙間は小さい.

以上のように $6 \mathrm{~mm}$ 球の場合には, 粒状体が整然と配列す ると大きな減衰比が得られることが分かった。他の粒状体 直径でも同様の傾向が見られるかを検討する. 粒状体とし て直径 $10 \mathrm{~mm}, 12.5 \mathrm{~mm}$ のものを用意した，実験結果を図 15 に示す. $10 \mathrm{~mm}$ 球では奥行き寸法 $18.7 \mathrm{~mm}$ の場合に, $12.5 \mathrm{~mm}$ 球では奥行き寸法 $23.3 \mathrm{~mm}$ の場合に，ほぼ最大の 減衰比を示すことが分かる，以上述べた各条件では，粒状 体は整然とした配列をしており,粒状体間の隙間は小さい.

以上を総合すると，粒状体が整然と配列するような，粒 状体直径と容器奥行き寸法とを選択寸れば, 大きな減衰比 が得られると言える。

\section{$4 \cdot 4$ 容器の奥行き寸法と減衰比}

先に述べた粒状体直径 $(10 \mathrm{~mm}, 12.5 \mathrm{~mm})$ よりもやや小 さい直径のものを対象として実験を行った。粒状体直径 $3 \mathrm{~mm}, 5 \mathrm{~mm}, 8 \mathrm{~mm}$ の結果を図 16(a)〜 (c) に示す.

ここで, 例えば，図(a)に注目する. 粒状体直径が小さく $(3 \mathrm{~mm})$ になると, 粒状体容器の奥行き寸法の可変範囲にお いて, 粒状体が整然と配列する場合が何度か生じる。この 整然と配列する場合の結果を図中に白丸印で指し示す．白 丸印の上の列の数は，図 13 の上方から見た写真のように， 斜めに整然と配列した粒状体の列数を示している. 奥行き 寸法が増加して, 粒状体の列数が増加すると, 減衰比が大 きくなっていることが分かる.

次に, 粒状体が整然と配列しない場合，つまり，奥行き寸 法が $18 \mathrm{~mm}, 20 \mathrm{~mm} ， 25 \mathrm{~mm}$ の結果を見てみる。この場合

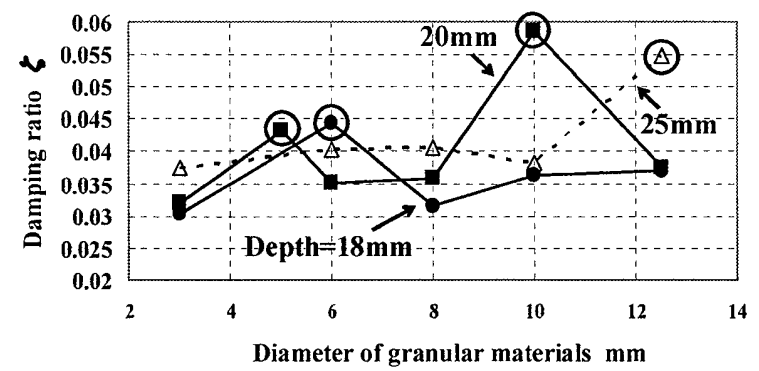

Fig.10 Relationship between damping ratio and diameter of granular materials
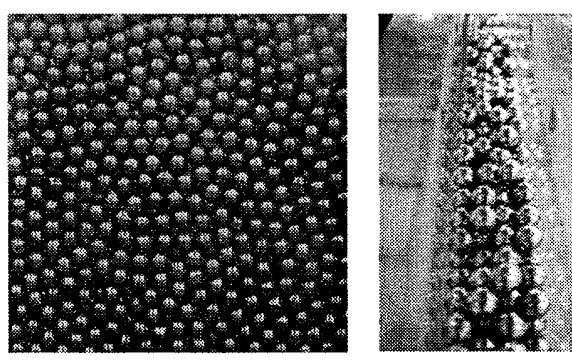

Fig.11 Arrange of granular materials (Diameter:6mm,Depth:20mm)
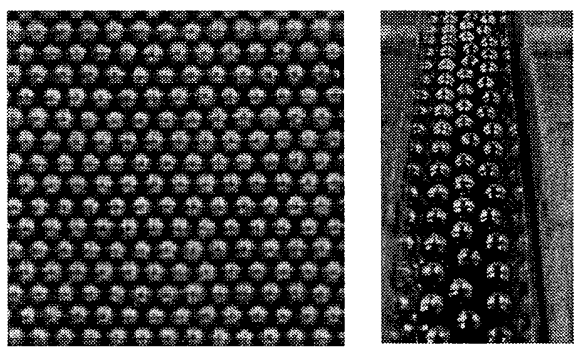

Fig. 12 Arrange of granular materials (Diameter:6mm,Depth:18mm)
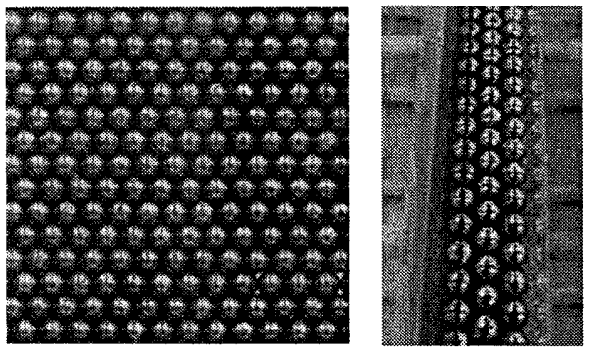

Fig. 13 Arrange of granular materials (Diameter:6mm,Depth: $16.4 \mathrm{~mm}$ )

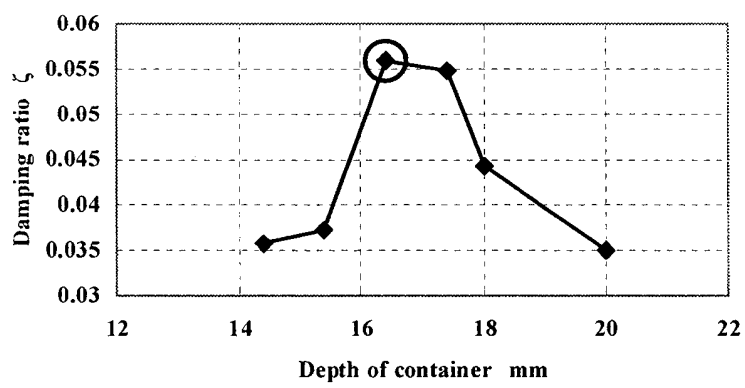

Fig. 14 Relationship between damping ratio and depth of container(Diameter: $6 \mathrm{~mm}$ ) 
の減衰比は, 粒状体が整然と配列する場合の結果と比べて, 小さいことが分かる.ただ,ここでも奥行き寸法が $18 \mathrm{~mm}$, $20 \mathrm{~mm}, 25 \mathrm{~mm}$ と大きくなるに従って，減衰比が増加する 傾向にある。

以上述べた容器の奥行き寸法と減衰比との関係は, 粒状 体直径 $5 \mathrm{~mm}$ (図 (b))，8mm（図(c)）の結果にも同様に認 められる。このように奥行き寸法が大きくなるに従って減 衰比が大きくなるのは, 奥行き寸法を広げることにより粒 状体が動きや寸くなったために起こったのではないかと推 察している.

\section{5. 結言}

粒状体ダンパを有する 1 自由度振動系モデルを製作し， その減衰特性を検討した. 粒状体の運動を高速度ビデオカ メラで撮影し, その運動を解析して, 減衰特性との関係を 検討した. さらに, 粒状体直径と粒状体容器の奥行き寸法 を変更してダンパの制振特性を評価した。その結果，以下 のことが明らかになった。

(1)粒状体の「並進」あるいは「回転」の質量が増加すると， 減衰比は大きくなる。

(2)粒状体直径と粒状体容器の奥行き寸法とが, 粒状体の配 列が整う寸法関係になると, 減衰比が大きくなる.

(3)粒状体容器の奥行き寸法を増すと減衰比が大きくなる傾 向がある。

\section{参考文献}

(1) 佐伯, 今西, 高野, 個別要素法による粒状体衝䌘ダンパ 门解析，機論，66-652, C (2000), pp.3828-3833.

(2) Mao, K. M., Wang, M. Y., Xu, Z. W., and Chen, T. N., Simulation and Characterization of Particle Damping in Transient Vibrations, Trans. ASME, J. Vibration and Acoustics, 126(2004), pp. 202-211.

(3) T. Sato, K. Tanaka, S. Aida, Y. Mouri, Vibration Isolation in a System Using Granular Medium, JSME Int. J., Vol. 38, No. 3, C(1995), pp. 434-440.

(4) 瀬畑, 牧野, 平石, 中村, 佐藤, 望月, 佐藤, 粒状体を用 いた静音リンク装置の開発，日本音響学会講演論文集 , (2000), pp.65-66.

(5)伴, 佐藤, 谷島, 田中, 粒状体ダンパの基礎的研究 , D\&D2005 講演論文集, (2005)，CD-R0M (6ページ)

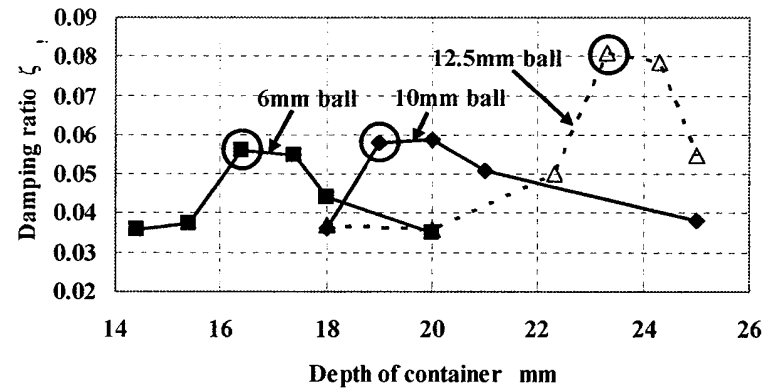

Fig. 15 Relationship between damping ratio and depth of container

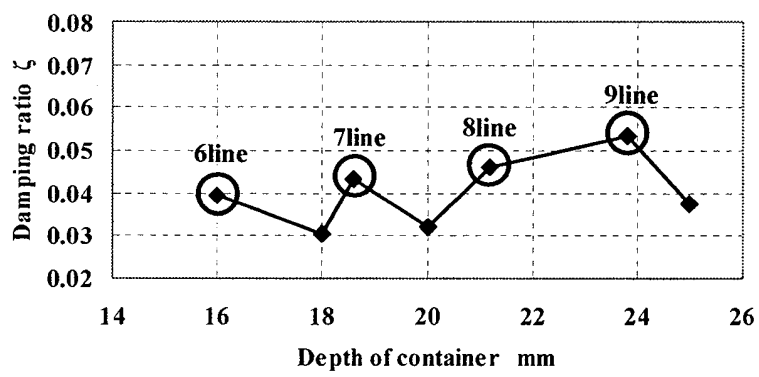

(a) Diameter:3mm

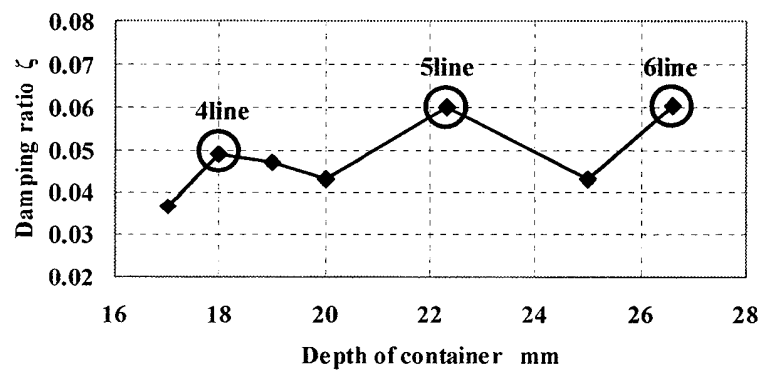

(b) Diameter:5mm

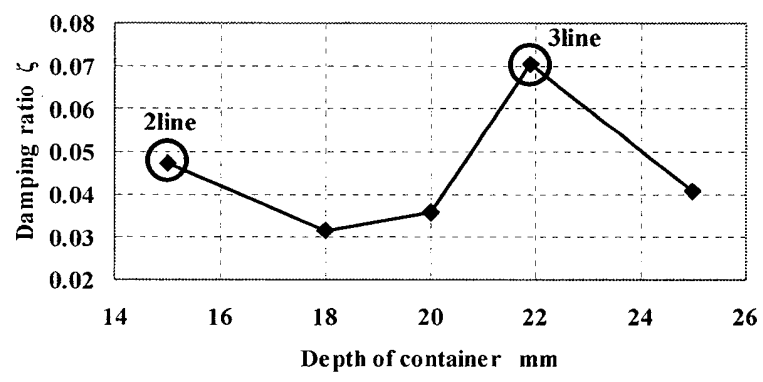

(c) Diameter: $8 \mathrm{~mm}$

Fig. 16 Relationship between damping ratio and depth of container 